\title{
A Model for the Influential Factors of the Autonomous Learning Ability of Japanese Majors
}

\author{
https://doi.org/10.3991/ijet.v15i12.14531 \\ Yiping Li $(\bowtie)$, Dongmei Jin \\ Jilin Institute of Chemical Technology, Jilin, China \\ Liyiping312@hotmail.com
}

\begin{abstract}
The autonomous learning of Japanese majors is affected by various factors and the learning effect is generally undesirable. To solve the problem, this paper aims to develop a model for the influencing factors of the autonomous learning of Japanese majors. Firstly, the authors explored the problems and influencing factors of autonomous learning of Japanese majors. On this basis, several suggestions were put forward to solve these problems. Next, gray system theory (GST) and analytical hierarchy process (AHP) were adopted to establish the indicator system and the assessment model for the autonomous learning effect of Japanese majors. The proposed model can effectively assess the effect of autonomous learning among Japanese majors, providing a good reference for the learning of minor language among college students.
\end{abstract}

Keywords-Japanese majors, autonomous learning, gray system theory (GST), analytical hierarchy process (AHP), influencing factors

\section{Introduction}

Autonomous learning is an important manifestation of college students' learning ability. With the continuous progress of science and technology, the market's demand for college students has become increasingly diversified, so the comprehensive ability of college students has received more attention from the society. Therefore, in order to better adapt to the development of modern society, college students need to pay more attention to the improvement of self-learning ability in addition to the professional qualities, as a result, autonomous learning has become a key part of the quality education in higher education [1-3]. The Japanese major is a minor language major set up by some colleges and universities, it plays an important role in the communication and cooperation between China and Japan, which has made these schools begin to pay attention to the Japanese learning of college students, so that the Japanese major graduates could better adapt to the development requirement of the society after their graduation [4-6]. As an effective means of language learning, autonomous learning can also be applied to the minor language learning such as Japanese, and this learning method has gradually received attention from researchers who have successively conducted a series of studies and analysis on it. For example, Nobuyuki Ogawa ana- 
lyzed the educational practice issues that improve students' learning initiative, he not only explored how to cultivate students' ability to describe engineering-related issues in English, but also analyzed the promotive role of professional English teaching interaction [7]. Kurhila and Kotilainen explored how to combine the activities of the outside world with the teaching goals and practices of (formal) language teaching, thereby promoting students' learning activities and their self-regulation under different teaching scenarios [8]. Shen studied the influencing factors and training strategies of foreign language autonomous learning ability in the era of big data [9]. Zhong analyzed the influence of advanced Japanese extracurricular self-study on the development of the learners' autonomous learning ability [10]. Zhang studied the paths to improve and cultivate college students' learning interest in Japanese language teaching under the new national framework [11]. He took specific schools as examples to discuss the teaching content of Japanese as the second language and its implementation strategies under the new national standards [12]. Burgh-Hirabe used some exploratory cases as examples to study and analyze the Japanese learning motivations in English-speaking countries [13].

Currently, there are still shortcomings with the systematicness and completeness of the studies on the influencing factors for the autonomous learning ability of Japanese majors, these studies failed to see the problem from the root, and there's still room for further research in terms of influencing factors, strategy implementation, evaluation system, and evaluation model, etc. To this end, based on a literature review and by referring to key methods and models in existing research results, this paper attempts to give a systematic discussion on the influencing factors for the autonomous learning ability of Japanese majors, and applies GST and AHP to construct indicator system and evaluation model for the autonomous learning effect of Japanese majors [14-18]. The content of this paper consists of six parts: the first part is an overview of the implementation situations of Japanese major students' autonomous learning; the second part discusses the characteristics of autonomous learning ability of Japanese majors; the third part analyzes the factors influencing the autonomous learning effect of Japanese majors; the fourth part proposes implementation strategies and paths for cultivating the autonomous learning ability of Japanese majors; the fifth part constructs the indicator system and evaluation model for the autonomous learning of Japanese majors, and analyzes the cultivation effects; the sixth part gives the conclusion.

\section{Manifestations of Autonomous Learning Ability of Japanese Majors}

\subsection{Ability to acquire professional knowledge}

For Japanese majors, the ability to acquire professional knowledge is an intermediary between knowledge learning and knowledge innovation, it's a basic ability for them to absorb, digest, convert and apply professional knowledge, and thereby realizing knowledge output. As a learning method for minor languages, autonomous learning is an effective method for extracurricular learning, and its most basic function is 
to facilitate the absorption and digestion of knowledge of Japanese major courses. Through autonomous learning, students acquire extracurricular knowledge related to Japanese major or professional knowledge they haven't got time to learn in class, thereby improving their basic professional literacy.

\subsection{Learning innovation ability}

Learning innovation is an important manifestation of minor language learning. For the learning of minor languages such as Japanese, the learning process and subsequent application require certain language environment; the learners of minor language may not have a good learning environment or a broad application field, so it requires the Japanese majors to form certain mindset of autonomous learning during the learning process, make use of their knowledge acquire and reserve skills to innovate their Japanese language learning, so as to obtain richer professional knowledge and stronger learning innovation ability.

\subsection{Self-management ability}

Classroom teaching for Japanese majors is generally instructed by teachers during the class. Classroom rules and learning disciplines give certain restrains and controls over the Japanese majors during the learning process; however, they don't have instructors or supervisors for their autonomous learning, and have to depend on their own learning willingness. If a student has poor ability in self-control or selfmanagement, he/she is easily affected by external environmental factors, and can hardly concentrate on learning, which will seriously affect the learning effect, resulting in that the expected learning results can hardly be achieved. Therefore, if Japanese majors want to achieve good autonomous learning effect, they must have strong selfmanagement ability.

\subsection{Teamwork ability}

The implementation of autonomous learning for Japanese majors often requires the collection, summarization, and organization of learning resources such as specialized Japanese knowledge, professional materials, and technical information. In this process, both online learning resources (such as online courseware, videos, electronic documents, etc.) and offline learning resources (such as printed textbooks, study reports, library materials, etc.) will require multiple students to cooperate, acquire, share and manage these learning resources together, so as to improve their learning efficiency and quality. During the process of autonomous learning, Japanese majors need to work in teams and study collaboratively, based on study groups or teams, they have to exert teamwork spirit, complement and help each other to achieve the optimal learning efficiency of the entire study group. 


\subsection{Practical application ability}

As a language major, Japanese language courses also focus on the cultivation of students' comprehensive ability in listening, speaking, reading, writing, and translating. In the process of autonomous learning, every time a student exposes to a new language knowledge is an autonomous learning process, which requires he/she to do a lot of imitation, exercises and practice of language learning links such as listening, speaking, reading, writing, and translating, etc., so as to effectively improve the comprehensive language fluency. Therefore, in the process of autonomous learning, we must fully mobilize Japanese majors' initiative and enthusiasm for autonomous learning, and provide more opportunities for them to practice and improve their ability to use the Japanese language. In this way, their professional quality could be improved effectively, and their ability in problem discovering and solving could be cultivated, as a result, their ability in thinking and innovating could be enhanced during the autonomous learning process.

\subsection{Learning translation ability}

For Japanese majors, regardless of classroom learning or autonomous learning, the ultimate goal of learning is not just remembering the professional knowledge, what's more important is the translation of professional knowledge. For Japanese majors with stronger learning ability, what is lacking in the autonomous learning process is not the professional Japanese language knowledge, but the ability to translate the knowledge into academic achievements that could promote the development of the subject or the technology. Generally speaking, for Japanese majors who acquired more professional knowledge through autonomous learning, their ability to reserve professional knowledge is stronger; but if the knowledge reserves cannot be converted into their personal technical or academic capabilities, eventually, they won't be able to serve the society effectively. As a result, in the process of autonomous learning, Japanese majors need to prepare themselves from various aspects such as clarifying personal learning background, constructing personal learning structure, building professional knowledge reserves, and enhancing personal knowledge application, etc., so as to improve their learning translation ability.

\section{Influencing Factors for Autonomous Learning Ability of Japanese Majors}

Although autonomous learning has a very important positive effect on improving the comprehensive quality of Japanese majors, due to the existence of some influencing factors, there're still some limitations in the autonomous learning ability of Japanese majors. 


\subsection{Weak faculty and insufficient support to autonomous learning}

Japanese major is a minor language major in colleges and universities. The graduates of this major have a narrow employment scope, they generally choose to work in language schools and foreign trade services. Since Japanese is not an international language, and there're not many countries in the world that use Japanese as their language for international trades, so these situations have resulted in that the employment prospects of Japanese majors are very uncertain. The less-than-ideal employment prospects affect the admissions of colleges and universities, which in turn affect the cultivation of Japanese majors, and thus forming a vicious circle. Therefore, under such conditions, the Japanese major is often not a valued major in colleges and universities, and its faculty is relatively weak; there're big gaps in terms of introduction of senior teachers, basic discipline construction, and teaching and research investment, etc.; therefore, under normal circumstances, the Japanese major faculty in colleges and universities is usually only set up for the classroom teaching of Japanese major, while ignoring the autonomous learning requirement of Japanese majors, thus failing to give sufficient support for the autonomous learning of Japanese majors.

\subsection{Planless curriculum design and scant instruction for autonomous learning}

The traditional Japanese major curriculum design generally focuses on the classroom teaching, and the main content focuses on the various links of classroom teaching, including listening, speaking, writing and reading in Japanese language; the traditional method designs corresponding teaching materials, textbooks, syllabuses, and teaching diaries for these links; some colleges and universities have even formed their unique teaching methods or teaching modes to give instructions to the classroom teaching of Japanese major. However, when autonomous learning is concerned, as the scope of autonomous learning is wider, and cultivation goal of autonomous learning is not so clear, which makes the autonomous learning of Japanese major students lack the support of systematic textbooks or schemes; the implementation of their autonomous learning is planless, which has greatly affected the learning effect.

\subsection{Poor self-management of students and inadequate emphasis on autonomous learning}

The age of college students is generally between 18 and 22. Many of them studied really hard in their high schools, but after entering colleges, they suddenly relaxed not only psychologically, but also in their learning attitude; for minor language majors such as Japanese, the students' learning task loads are often lighter than students majored in science and engineering, so the relaxation phenomenon is even worse. College students generally live in school dormitories or rented houses outside the campus, far away from their families and parents, lacking the necessary supervision of parents, plus college teachers couldn't give each of them enough attention since there're too many students to take care of, the students become lazy in their life and study. Therefore, for individual students, if one has good learning habits and self- 
management ability, he or she could indeed improve the professional literacy through autonomous learning once they spend some time on it; but if one hasn't got a good self-management ability and unable to realize the importance of autonomous learning, he or she would have no desire to make progress in autonomous learning, over time, their professional knowledge reserve capacity will decline rapidly, and the effect of autonomous learning will be dissatisfactory.

\subsection{Missing or incomplete construction of learning platform for autonomous learning}

Since minor language majors such as Japanese are often less valued by executives of colleges and universities, the construction of minor language disciplines or majors is incomplete; therefore, the investment in the teaching and research of Japanese major is quite limited, which can hardly provide a good support to the development of the Japanese major. However, for the autonomous learning of college students, the construction of autonomous learning platforms is quite necessary, especially with the rapid development of science and technology, such as multimedia technology, digital technology, network technology, computer technology, information technology, big data technology, AI technology, and VR technology, etc., the teaching modes of colleges and universities have undergone great changes, many science and engineering majors or disciplines have established corresponding platforms to support their teaching or scientific research, such as multimedia teaching and research laboratories, digital learning centers, information teaching and research platforms, data management systems, online learning systems, and online libraries, etc. However, for minor language majors such as Japanese, they often do not have such technical support, and cannot provide the necessary intelligent platforms for the autonomous learning of Japanese majors, which has a great impact on the learning efficiency and quality of the autonomous learning of Japanese majors.

\subsection{Bad learning environment and failing to trigger students' interest}

The learning environment of autonomous learning of Japanese majors refers to a kind of recognition space created for the co-learning and interaction of Japanese majors in which they could use technical resources and professional knowledge to find solutions to their learning problems. The environment for the autonomous learning of Japanese majors includes physical space, activity space, and psychological space; the environment requires both abundant resources for the autonomous learning of Japanese majors, and the human-computer interaction factors among autonomous learners. Only when the environment is conductive for the Japanese majors to carry out autonomous learning activities could it effectively improve the effect of the autonomous learning of Japanese majors. Therefore, besides learning resources and technical resources, the environment for the autonomous learning of Japanese majors should also take cognitive learning tools, autonomous learning strategies, and external factors into consideration. However, judging from the current environment of autonomous learning for Japanese majors in colleges and universities, the hardware and software con- 
figuration could not well serve the needs of autonomous learning for Japanese majors, which has resulted in a lacking of the atmosphere for autonomous learning, and the students show no interest or enthusiasm for the learning of professional knowledge, which has affected the autonomous learning effect of Japanese majors.

\section{Implementation Strategies and Paths for the Cultivation of Autonomous Learning Ability of Japanese Majors}

The JF Japanese Education Standard (hereinafter referred to as the JF Standard) is a tool for conducting Japanese language education and evaluating the learning effect of Japanese language. Through JF standard, we can understand our Japanese proficiency, and this standard could also be applied to the aspects of curriculum setting, textbook development, and examination design. Based on the A Common European Framework of Reference for Languages: Learning, Teaching, Assessment (abbreviated as CEF) published by the European Union in 2001, in 2010, the Japan Foundation (JF) issued the JF Japanese Education Standard 2010, which provides a new criterion for the global Japanese education, learning, and evaluation. The "can-do mode" under this standard takes "what tasks could the learner complete" during the language use activities as the teaching goal, and the "language communication ability" as the main evaluation method. This mode has changed the traditional teaching method centered on grammar and vocabulary, through the task-oriented teaching method, it improves students' ability in fulfilling tasks and cross-cultural communication. By analyzing the manifestations and influencing factors of the autonomous learning of Japanese majors, this paper proposes a few strategies and paths for the cultivation of autonomous learning ability of Japanese majors based on the above-mentioned standard.

\subsection{Strengthen Japanese major faculty and improve teaching quality}

Strengthening faculty competence and improving teaching quality are basic conditions for ensuring the effect of autonomous learning of Japanese majors. In order to strengthen faculty competence and improve teaching quality, we should pay close attention to the following aspects: first, the professional ability and literacy of Japanese teachers, only teachers with high professional literacy could cultivate high quality Japanese major graduates; second, the construction of a hierarchical faculty, a faculty team with senior-middle-junior level teachers should be constructed so that the teaching quality of Japanese major could achieve sustainable development; third, the introduction of senior Japanese teaching talents, we should cultivate famous teachers for minor language majors such as Japanese, accomplished teachers can better train skilled students, they could point the right directions for the autonomous learning of students, which is conductive to the cultivation of Japanese majors; fourth, the basic input of Japanese language major, including both the hardware facilities and software services for Japanese majors, which provide the basic guarantees for the teaching of Japanese major. 


\subsection{Compile excellent Japanese textbooks and build quality course system}

For Japanese major students, both classroom learning and autonomous learning require the support of professional textbooks and teaching schemes, which provide a guidance for the direction of the teaching of Japanese major. In order to provide better professional and directional guidance resources and materials for the autonomous learning of Japanese majors, we need to compile a series of excellent textbooks with Japanese major characteristics, set up a series of quality courses with Japanese major characteristics, and build an excellent Japanese major course system with a certain scale. In order to support the autonomous learning of Japanese majors more effectively, the compilation of Japanese textbooks and the setting of quality courses need to pay attention to four aspects, namely logic, scientificity, contemporaneity and systematicness. Logic means that the compilation of Japanese textbooks and the setting of quality courses must conform to the development logic of the planning of the discipline; the scientificity means that the compilation of Japanese textbooks and the setting of quality courses must have a scientific and reasonable basis; the contemporaneity means that the compilation of Japanese textbooks and the setting of quality courses must be in line with the characteristics of the development of the times; and the systematicness means that the compilation of Japanese textbooks and the setting of quality courses should have a discipline or subject system.

\subsection{Construct intelligent platform and use intelligent technologies to improve autonomous learning efficiency}

With the rapid development of modern intelligent technology and the acceleration of the learning rhythm of college students, the demand for intelligent higher education platforms has become more and more urgent. In terms of Japanese major, a good Japanese major autonomous learning platform would make it easier for Japanese majors to carry out autonomous learning, it can not only provide huge amounts of Japanese major learning resources and materials, but also effectively save the students' time and energy in autonomous learning and improve their learning efficiency and quality. Therefore, it is necessary to comprehensively apply network technology, computer technology, information technology, big data technology, multimedia technology, digitization technology, VR technology, knowledge management technology, and other technologies to the development of the autonomous learning platform and system for Japanese majors. Moreover, during the development process, both hardware facilities such as multimedia classrooms, digital centers, information centers, and software systems such as data management system, online library, online learning system (e.g. MOOC, flipped classrooms, rain classroom) should be constructed for the autonomous learning of Japanese majors. 


\subsection{Formulate systematic teaching plan and enhance students' learning interest}

The teaching of Japanese major should take students' professional quality as the ultimate goal and their learning interest as the entry point. Only when the students' learning interest has been triggered could their enthusiasm and passion for autonomous learning be fully stimulated, and they are willing to invest more time and energy in autonomous learning, which is more conductive to the knowledge absorption and conversion of the autonomous learning of Japanese majors. For this reason, it is of great significance to formulate a good teaching plan for the autonomous learning of Japanese majors. The author believes that the teaching plan of Japanese major needs to pay attention to the following three aspects: systematicness, hierarchy, and professionalism. The teaching systematicness means that the teaching process and method of Japanese major must have a strong logical system. The teaching hierarchy means that, for Japanese majors of different grades, specialized courses of different difficulty levels should be set up for them respectively, and attention should also be paid to the connection between the professional courses of different levels. The teaching professionalism means that the teaching plan of Japanese major should extract and refine professional knowledge from different teaching links, so as to effectively impart the professional knowledge of Japanese listening, speaking, writing, reading and other teaching links, which is more conductive to the autonomous learning of Japanese majors.

\subsection{Reform teaching mode and enhance autonomous learning conversion ability}

It has been proved through practice that there is a serious disconnect between the traditional teaching mode and the requirement of modern higher education. The traditional teaching mode is exam-oriented and focuses on the stereotyped teaching of professional knowledge, failing to fully explore the learning potential of college students. On the contrary, modern higher education is quality-oriented and focuses on the comprehensive quality of the advanced talents. As an effective learning method in the training of advanced talents, autonomous learning also needs to be reformed and innovated based on the traditional teaching mode, so as to facilitate the improvement of the effect of autonomous learning. From the perspective of promoting the autonomous learning ability of Japanese majors, the reform of the teaching mode of Japanese majors must pay attention to the teaching concepts, teaching tools, teaching methods, and other aspects. The teaching concepts should be contemporary, the teaching tools should be diverse, and the teaching methods should be advanced; moreover, we should also pay special attention to the construction of industry-university-research integration model for the Japanese major, and cultivate students' ability in combining theory with practice, which is of very important significance for the improvement of the autonomous learning conversion ability of Japanese majors. 
4.6 Strengthen the assessment of the autonomous learning ability and improve its recognition

The implementation process of the autonomous learning mode of Japanese major is generally a process of gradual exploration and improvement. By effectively evaluating the effect of autonomous learning of Japanese majors and applying the improvement measures to the weak links based on the evaluation results, the functionality of the autonomous learning of Japanese majors could be improved. The autonomous learning ability of Japanese majors is the most direct reflection of the effect of autonomous learning, by effectively distinguishing the autonomous learning ability of Japanese majors and classifying the levels of the autonomous learning ability, we can analyze the learning problems under each autonomous learning ability category, and find out the cause for these problems, thereby giving corresponding improvement measures. The assessment of the autonomous learning ability of Japanese majors should pay attention to the content of two aspects: the construction of the assessment system, and the construction of the assessment model. The assessment system for the autonomous learning ability of Japanese majors should be able to reflect the autonomous learning ability of Japanese majors, and the assessment model for the autonomous learning ability of Japanese majors should be able to form quantified analysis results. The analysis results should be hierarchical and can be easily identified, so that targeted improvement strategies could be proposed for the autonomous learning of Japanese majors.

\section{Cultivation Effect of Autonomous Learning Ability of Japanese Majors}

Based on above analysis, in order to give effective evaluation for the cultivation effect of the autonomous learning ability of Japanese majors, this paper selected six kinds of abilities as the evaluation indicators for the autonomous learning ability of Japanese majors, including the ability to acquire professional knowledge, learning innovation ability, self-management ability, teamwork ability, practical application ability and learning translation ability; then an assessment system was constructed for evaluating the autonomous learning ability of Japanese majors, and AHP [19-20] was adopted to carry out weight analysis on the six evaluation indicators, and construct the corresponding indicator judgement matrix A as follows:

$$
\mathbf{A}=\left[\begin{array}{cccccc}
1 & 1 / 2 & 1 / 3 & 1 / 3 & 1 / 2 & 1 / 3 \\
2 & 1 & 2 / 3 & 1 & 2 & 1 / 2 \\
3 & 3 / 2 & 1 & 2 & 3 & 1 \\
3 & 1 & 1 / 2 & 1 & 2 & 2 / 3 \\
2 & 1 / 2 & 1 / 3 & 1 / 2 & 1 & 1 / 2 \\
3 & 2 & 1 & 3 / 2 & 2 & 1
\end{array}\right]
$$


The corresponding indicator weight sequence $\mathrm{W}$ is:

$$
\begin{aligned}
& W=\left\{w_{1}, w_{2}, w_{3}, w_{4}, w_{5}, w_{6}\right\} \\
& =\{0.069,0.158,0.261,0.169,0.100,0.243\}
\end{aligned}
$$

In order to more clearly distinguish the hierarchies of the autonomous learning ability of Japanese majors, this paper divided them into 6 hierarchical categories: outstanding, very good, good, average, poor, and very poor, respectively are: LV1, LV2, LV3, LV4, LV5, and LV6. Assume all evaluation indicators had been subject to the unified scale processing, and the range of the processed values was between $0-1$, then the gray classic domains of the 6 hierarchical categories can be established as $V\left(L V_{1}\right)=[0.9,1.0], \quad V\left(L V_{2}\right)=[0.8,0.9], \quad V\left(L V_{3}\right)=[0.7,0.8], \quad V\left(L V_{5}\right)=[0.6,0.7]$,
$V\left(L V_{5}\right)=[0.4,0.6]$ and $V\left(L V_{6}\right)=[0,0.4]$

In consideration of the generality of the expression, the $\mathrm{j}$-th gray classical domain of the i-th evaluation indicator is expressed as $V\left(L V_{i j}\right)=\left[v\left(L V_{i j}\right)^{a}, v\left(L V_{i j}\right)^{b}\right]_{\text {; }}$ assuming that the value of the object $\mathrm{P}$ to be evaluated with regard to the $\mathrm{i}$-th evaluation indicator is $V_{P}(i)$, then the Euclidean distance $d_{\square}(i j)$ of the object $\mathrm{P}$ to be evaluated and the $\mathrm{j}$-th gray classical domain with regard to the $\mathrm{i}$-th evaluation indicator is expressed as: [21-23]

$$
d_{\square}(i j)=\sqrt{\frac{\left|V_{P}(i)-v\left(L V_{i j}\right)^{a}\right|^{2}+\left|V_{P}(i)-v\left(L V_{i j}\right)^{b}\right|^{2}}{2}}
$$

By applying the gray correlation analysis [24-25], the gray correlation coefficient $\gamma_{i j}(P)$ of the object $\mathrm{P}$ to be evaluated and the $\mathrm{j}$-th gray classical domain with regard to the $\mathrm{i}$-th evaluation indicator is expressed as:

$$
\gamma_{i j}(P)=\frac{\min _{1 \leq i \leq m} \min _{1 \leq j \leq n}\left(d_{\square}(i j)\right)+\rho \max _{1 \leq i \leq m} \max _{1 \leq j \leq n}\left(d_{\square}(i j)\right)}{\left(d_{\square}(i j)\right)+\rho \max _{1 \leq i \leq m} \max _{1 \leq j \leq n}\left(d_{\square}(i j)\right)}
$$

where, $\mathrm{m}$ indicates the number of evaluation indicators and satisfies $i=1,2, \cdots, m$; $\mathrm{n}$ indicates the number of assessment categories and satisfies $j=1,2, \cdots, n$; $\rho$ is the identification coefficient, $\rho \in[0,1]$ and its value generally takes $\rho=0.5$.

Considering the weights of the evaluation indicators, the weighted gray correlation $\theta_{j}(P)$ between the object $\mathrm{P}$ to be evaluated and the $\mathrm{j}$-th gray classical domain is expressed as: 


$$
\theta_{j}(P)=\sum_{i=1}^{m}\left(w_{i} * \gamma_{i j}(P)\right)
$$

Then according to the optimization principle of multi-attribute grey correlation analysis, if there is:

$$
\theta_{j}(P)=\max \left\{\theta_{1}(P), \theta_{2}(P), \cdots, \psi_{n}\right\}=\theta_{k}(P), 1 \leq k \leq n
$$

It indicates that the assessment category of object $\mathrm{P}$ is $L V_{k}$, then for the weak links of the autonomous learning under category $L V_{k}$, corresponding improvement measures could be taken to enhance the autonomous learning effect of object $P$.

\section{Conclusion}

This paper explored and analyzed some key links and content of the model constructed for the influencing factors of the autonomous learning of Japanese majors, and pointed out essential problems in the manifestations of the autonomous learning ability of Japanese majors, it analyzed the influencing factors and problems existing in the implementation process of the autonomous learning of Japanese majors in depth, and proposed a series of implementation strategies and measures for the cultivation of the autonomous learning ability of Japanese majors, which had a very important effect on the improvement of the autonomous learning ability of Japanese majors. At the same time, based on related theories and by comprehensively using relevant methods, this paper constructed assessment system and assessment model for the evaluation of the autonomous learning ability of Japanese majors, which could provide good guidance for improving the identification degree of the autonomous learning ability of Japanese majors and discovering the weak links in the autonomous learning ability of Japanese majors. In this paper, the model constructed for the influencing factors of the autonomous learning of Japanese majors is a deepening analysis of the existing research content, which has a very important role in effectively improving the autonomous learning ability of Japanese majors.

\section{$7 \quad$ Acknowledgement}

Study on the cultivation of College Students' Japanese learning ability under JF standard.

\section{References}

[1] Torres, W.J., Beier, M.E. (2018). Adult development in the wild: The determinants of autonomous learning in a Massive Open Online Course. Learning and Individual Differences, 65: 207-217. https://doi.org/10.1016/j.lindif.2018.06.003. 
[2] Zhang, N.N., Chen, J. (2019). Strategies for improving college students' autonomous learning ability under the background of "Internet + education". Education Modernization, (9): 111-115. https://doi.org/10.16541/j.cnki.2095-8420.2019.78.048.

[3] Qin, H.H., Tao, X.H. (2019). Constraints and Ability Cultivation of English Autonomous Learning in Independent College-Taking Jianghuai College of Anhui University as an example. The Journal of Shandong Agricultural Engineering College, 36(12): 147-148. https://doi.org/10.15948/j.cnki.37-1500/s.2019.12.069.

[4] Shabudin, M., Aisyah, A., Darus, S., Mimiko, N. Development of Teaching Materials and Utilization of Web 2.0 in Japanese Language Teaching and Learning. Procedia - Social and Behavioral Sciences, 118: 433-441. https://doi.org/10.1016/j.sbspro.2014.02.059.

[5] Fang, Y. (2019). Strategies of cultivating intercultural communicative competence in Japanese Teaching in Colleges and Universities. Journal of Beijing Institute of Graphic Communication, 27(12): 97-99. https://doi.org/10.19461/j.cnki.1004-8626.2019.12.026.

[6] Liu, Y. (2019). Research on the teaching method of Japanese education in Colleges and Universities. Education Modernization, (11): 178-179. https://doi.org/10.16541/j.cnki. 2095-8420.2019.95.081.

[7] Ogawa, N. (2018). Active Learning Strategy at a Collegewide Level in NIT, Gifu College . Procedia Computer Science, 126: 1994-2002. https://doi.org/10.1016/j.procs.2018.07.253.

[8] Kurhila, S., Kotilainen, L. (2020). Student-initiated language learning sequences in a realworld digital environment. Linguistics and Education, 56: 1-11. https://doi.org/10.1016/j.1 inged.2020.100807.

[9] Shen, W. (2018). A study on the influencing factors and training strategies of foreign language autonomous learning ability in the era of big data. Journal of Guangdong Institute of Public Administration, 30(1): 94-98. https://doi.org/10.13975/j.cnki.gdxz.2018.01.013.

[10] Zhong, Y. (2019). The influence of advanced Japanese extracurricular self-study on the development of learners' autonomous learning ability. Education Modernization, (8): 262263+275. https://doi.org/10.16541/j.cnki.2095-8420.2019.68.089.

[11] Zhang, T. (2019). The cultivation path of students' interest in learning in College Japanese Teaching under the framework of the new national standard. Western China Quality Education, (11): 154-158. https://doi.org/10.16681/j.cnki.wcqe.201921091.

[12] He, X.J. (2019). Practical teaching of Japanese as a second foreign language under the new national standard-Take Sichuan MinZu College as an example. Western China Quality Education, (10): 163-164. https://doi.org/10.16681/j.cnki.wcqe.201920090.

[13] Burgh-Hirabe, R.D. (2019). Motivation to learn Japanese as a foreign language in an English speaking country: An exploratory case study in New Zealand. System, 80: 95-106. https://doi.org/10.1016/j.system.2018.11.001.

[14] Bezuglov, A., Comert, G. (2016). Short-term freeway traffic parameter prediction: Application of grey system theory models. Expert Systems with Applications, 62: 284-292. https://doi.org/10.1016/j.eswa.2016.06.032.

[15] Li, M.X., Liao, R.Q., Dong, Y. (2019). Adaptive determination of time delay in grey prediction model with time delay. Ingénierie des Systèmes d'Information, 24(5): 519-524. https://doi.org/10.18280/isi.240509

[16] Javed, S., Mahmoudi, A., Niazi, A., Javed, S. (2018). A Critical Review: Shape Optimization of Welded Plate Heat Exchangers based on Grey Correlation Theory. Applied Thermal Engineering, 144: 593-599. https://doi.org/10.1016/j.applthermaleng.201 8.08.086.

[17] Hsieh, M.C., Wang, E. M.Y., Lee, W.C., Heieh, C.Y., Tsai, W., Wang, C.P., Huang, J.L., Liu, T.C. (2018). Application of HFACS, fuzzy TOPSIS, and AHP for identifying 
important human error factors in emergency departments in Taiwan. International Journal of Industrial Ergonomics, 18: 171-179. https://doi.org/10.1016/j.ergon.2018.05.004.

[18] Ghimire, L.P., Kim, Y. (2018). An analysis on barriers to renewable energy development in the context of Nepal using AHP. Renewable Energy, 129: 446-456. https://doi.org/10.10 16/j.renene.2018.06.011.

[19] Takaya, C., Cooper, I.R., Berg, M., Sarker, D. (2019). Offensive waste valorisation in the UK: Assessment of the potentials for absorbent hygiene product (AHP) recycling. Waste Management, 88: 56-70. https://doi.org/10.1016/j.wasman.2019.03.022.

[20] Butdee, S., Phuangsaleea, P. (2019). Uncertain risk assessment modelling for bus body manufacturing supply chain using AHP and fuzzy AHP. Procedia Manufacturing, 30: 663670. https://doi.org/10.1016/j.promfg.2019.02.094.

[21] Sánchez, A.D.B., Lavor, C. (2020). On the estimation of unknown distances for a class of Euclidean distance matrix completion problems with interval data. Linear Algebra and its Applications, 592: 287-305. https://doi.org/10.1016/j.laa.2020.01.036.

[22] Djellab, M., Mehallegue, N., Achi, A. (2019). Use of Neumann series decomposition to fit the Weighted Euclidean distance and Inner product scoring models in automatic speaker recognition. Pattern Recognition Letters, 125: 500-507. https://doi.org/10.1016/j.patrec.20 $\underline{19.06 .013}$.

[23] Ghorbel, E., Boonaert, J., Boutteau, R., Lecoeuche, S., Savatier, X. (2018). An extension of kernel learning methods using a modified Log-Euclidean distance for fast and accurate skeleton-based Human Action Recognition. Computer Vision and Image Understanding, 175: 32-43. https://doi.org/10.1016/i.cviu.2018.09.004.

[24] Ikram, M., Sroufe, R., Rehman, E., Shah, S.Z.A., Mahmoudi, A. (2020). Do Quality, Environmental, and Social (QES) Certifications Improve International Trade? A Comparative Grey Relation Analysis of Developing vs. Developed Countries. Physica A: Statistical Mechanics and its Applications, 545: 1-15. https://doi.org/10.1016/j.physa.2019. 123486.

[25] Tseng, M.L., Lim, M., Wu, K.J., Zhou, L., Bui, D.T.D. (2018). A novel approach for enhancing green supply chain management using converged interval-valued triangular fuzzy numbers-grey relation analysis. Resources, Conservation and Recycling, 128: 122133. https://doi.org/10.1016/j.resconrec.2017.01.007.

\section{$9 \quad$ Authors}

Yiping $\mathbf{~ L i}$ is a teacher and lecturer of foreign languages branch of Jilin Institute of chemical technology. Graduated from Changchun University of technology, master's degree in foreign linguistics and applied linguistics. She has been engaged in Japanese education, teaching and research for many years, and has successively taught basic Japanese, advanced Japanese, introduction to Japanese linguistics, Japanese Extensive Reading, Technical Japanese, History of Japanese Literatu and other major courses. Presided over and studied one university level scientific research project, mainly participated in one university level major scientific research project, three university level general scientific research projects, one university level general teaching and research project, and one university level excellent class member. She has published seven academic papers in provincial journals and university journals. With strong scientific research ability and rich teaching experience. 
Dongmei Jin, a lecturer of Jilin Institute of chemical technology, graduated from Northeast Normal University. She has been engaged in Japanese teaching and scientific research for many years, and has taught many basic courses and backbone courses of Japanese major. Presided over the research of a major project at school level, presided over and participated in a number of school level projects. He has published 9 academic papers, one of which is Chinese core journal. With strong scientific research ability and rich teaching experience.

Article submitted 2020-04-01. Resubmitted 2020-05-13. Final acceptance 2020-05-13. Final version published as submitted by the authors. 